\title{
Chapter 3: The Vessel of God - Voice vs. Mouthpiece
}

"Then he gave me a command that often makes me ashamed and causes me to weep because my utter unworthiness is obvious to my eyes; that is, he commanded me, a frail woman, to write this book out of God's heart and mouth. And so this book has come lovingly from Cod and does not have its origins in human thought" -

Mechthild of Magdeburg

\subsection{Called to Write}

As discussed in the preceding chapters, women were seen as inferior, prone to outside influences, and weak in mind and body. These perceived flaws meant that women were excluded not only from politics or public speech but also from writing. This chapter will focus on how the female prophets in question were, nevertheless, able to justify their writings by focusing on the production of text itself as well as on authorship, and on the voice that these women claim for themselves. Most of these women are painfully aware of the aforementioned restrictions, which can be seen at the beginning of several of their works, where they see the need to defend their writing. Julian, for instance, writes in her Short Text:

I beg you all for Cod's sake and advise you all for your own advantage that you stop paying attention to the poor, worldly, sinful creature to whom this vision was shown, and eagerly, attentively, lovingly and humbly contemplate Cod, who in his gracious love and in his eternal goodness wanted the vision 
to be generally known to comfort us all. [...] For if I look solely at myself, I am really nothing. (Revelations Short Text 9-10)

Here, she makes it clear that she herself is nothing, a sinful creature nobody should pay attention to. Instead, one should only contemplate God and completely forget the "symple creature unlettyrde leving in deadly flesh" (Showings 4).

Her complete self-effacement, however, is not only connected to being human and thus sinful, it is also a consequence of her being a woman: "But God forbid that you should say or assume that I am a teacher, for that is not what I mean, nor did I ever mean it; for I am a woman, ignorant, weak and frail" (Revelations Short Text 10-11). Julian wilfully assumes the negative connotations associated with women, their supposed weakness in body and mind. By doing so, she demonstrates her awareness of the cultural ramifications revelations of a female writer could have. Since she is familiar with Paul's teaching, stating that a woman is not allowed to teach and should keep quiet, she wants to make sure that the reader knows from the start that she is not teaching. With respect to this, Denise N. Baker maintains:

Julian is careful not to claim any special authority for herself in either the short or the long text. Fourteenth-century England was much more conservative in matters of spirituality than the Continent, where accounts of women's visionary experiences were quite numerous from the twelfth century on. As the first English woman identified as a writer, Julian is acutely aware that she may be criticized for violating St. Paul's prohibition [...] against women preaching. ("Introduction" $\mathrm{x}$ )

Although I agree with Baker that Julian knows that she might be criticised for her teaching, I do not agree that it was any different for women on the Continent.

Indeed, even though the accounts of women's visionary experiences were more numerous on the Continent, those women faced the same cultural restrictions as Julian. Gertrud of Helfta (1256-1301), for instance, a German mystic at the monastery at Helfta, states: "I considered it so unsuitable for me to publish these writings, that my conscience would not consent to do so; [...] [God] added further: 'I desire your writings to be an indisputable evidence of My Divine goodness in these latter times, in which I purpose to do good to many"' (qtd. in Petroff 229). Another mystic at Helfta, Mechthild of Magdeburg (c 1207-1282) similarly declares: 
Then he gave me a command that often makes me ashamed and causes me to weep because my utter unworthiness is obvious to my eyes; that is, he commanded me, a frail woman, to write this book out of Cod's heart and mouth. And so this book has come lovingly from Cod and does not have its origins in human thought. (Book IV, Chapter 2)

Both of these women see the need to defend their writings as women. Like Julian, they state their unworthiness and acknowledge that, by virtue of being women they are unsuited for the task. Although people on the Continent were more accustomed to visionary writings by women, both Gertrud and Mechthild began their writings in the same fashion as Julian.

However, as soon as the self-effacement is displayed and Julian admits to her shortcomings, she also establishes her authority. In the first quote, she states that God wanted the vision to be known and that she was the only one to be entrusted with it. Thus, she is merely the intermediary between God and all Christians, and she is not a priestess. Furthermore, shortly after explaining that as a woman, she is ignorant and weak, she maintains: "Just because I am a woman, must I therefore believe that I must not tell you about the goodness of God, when I saw at the same time both his goodness and his wish that it should be known" (Revelations Short Text 11). In the Long Text, she removes most of the personal pieces, such as her mother standing over her and closing her eyes (Revelations Short Text 16), as well as the passage above about her as a teacher. However, in the Long Text she becomes much more self-confident. As we have seen in chapters one and two, Julian, although a "symple" and "unlettyrde" woman, is able to speak against the Church's teachings and participate in the political landscape of her time. Her theodicy is very different from that of her contemporaries. By combining sensuality and substance she creates a sophisticated universal salvation theory. In stating her unworthiness and the supposed inferiority of her gender, she not only displays her humility, she also establishes her authority in and through her work in the most powerful way, namely, through God who only gives His revelations to her, wanting her to spread them further onto every Christian. Admission of her inferiority as a woman and her illness are what justify her text in the first place, making her more suitable for voicing God's truth.

The same holds true for Margery. At several points in her Book, she describes herself as "a synful caytyf" (41) or says: "I am the most unworthi creatur that evyr thow schewedyst grace unto erth" (132). Once again, sinfulness and unworthines are used by a female visionary writer to describe herself. Despite 
her being an unworthy sinner, Margery is, nevertheless, commanded by God to write her Book: "Aftyrward, whan it plesyd ower Lord, he comawnded hyr and charggyd hir that sche schuld don wryten hyr felyngys and revelacyons and the forme of her levyng, that hys goodnesse myth be knowyn to alle the world" (46-47). By stating that God commanded her to write the book, she is able to claim that she as a woman would otherwise not have written or published anything and that she is only doing God's bidding. As with Julian's revelations, Margery's Book is to be shown to the entire world because her way of living and her revelations set an example for everyone to follow. God's wish for her to publish her writings frames the entire Book and is not only stated at the beginning but is also the theme of the last few chapters of the first part. There, God tells her again: "yet shulde ye not plesyn me mor than ye don wyth yowr writyng, for, dowtyr, be this boke many a man schal be turnyd to me and belevyn therin" (379). The message here is that, more than anything that is written in the Book about her life and her good works, it is the writing of the Book itself that pleases God the most as the Book will persuade people to believe in Him.

In addition, it is not only God who gives testimony to Margery's writings. Shortly after this passage, while she is occupied with the writing of the Book, we read the following: "And oftyn in the menetyme, whan the creatur was in cherche, owr Lord Jhesu Crist, wyth hys gloryows modyr and many seyntys also, comyn into hir sowle and thankyd hir, seying tht thei wer wel plesyd wyth the writyng of this boke" (382). Thus, Christ, his mother, and many saints also come to her and thank her for writing the Book. They give everything that is written in the Book credence and the highest possible authority. Moreover, as shown in the first chapter, weakness and illness are used to show God's special grace for these visionary writers and this topos is also used in Margery's text in connection to writing. The reader learns that Margery was ill several times while the Book was being written, but as soon as she was set on the task, "sche was heil and hoole sodeynly in a maner" (383). This demonstrates that the writing and the Book clearly come from God, who is able to make her healthy again. Her text is set apart from other writings in that it is commanded by God and is blessed by Christ, his mother and many saints. The truthfulness of revelations, in general, is explicitly addressed in the last paragraphs of the Book:

And sumtyme tho that men wenyn wer revelacyonis, it arn deceytys and illusyons, and therfor it is not expedient to yevyn redily credens to every 
steryng, but sadly abydyn and prevyn yf thei be sent of Cod. Nevyrthelesse as to this felyng of this creatur, it was very trewth schewyd in experiens. (383384)

The point here is that, while some revelations can be illusions and one should not believe everything that is said or seen, the revelations Margery has seen are the truth and God is witness to this. His command and her testimony lend her writings the best possible authority.

The seventeenth century was no different in this regard. Commenting on women's writings in the 1650s, Elaine Hobby states:

Women writing for publication in the period exposed themselves to adverse judgement, and their writings therefore commonly included justifications for their unfeminine boldness. It is this consciousness of the need to justify their activity that unites the writings of the decade. ("Discourse So Unsavoury"' 17)

Indeed, throughout the seventeenth century, women still felt the need to justify their writings even though women were publishing more works during this period than in the Middle Ages. In the Report and Plea, the first thing that Trapnel writes to her reader is the following: "The Lord, and my Father (Courteous Reader) [have] put me upon this work and imployment. I pray don't call it idleness, lest you would be likened to those who call good evil, and evil good; and put darkness for light, and light for darkness" ("To the Reader"). Again, it is God who wants her to write and publish her work and she even cautions the reader not to call it idleness as it comes from God rather than from herself.

In contrast to The Cry of a Stone, Report and Plea is not written by a scribe but by Trapnel herself who has been "[c]ommended for the justification of the Truth, and satisfaction of all men, from her own hand," as the Title Page says. The Title Page further states that it is a narrative of her journey from London to Cornwall whose purpose it is to show that the people are against the reign of Christ because they treat her in a "harsh, rough, boisterous, rugged, inhumane, and uncivil" way. The implication here is that since she has been singled out by God to write down her journey, everything that people say to her is ultimately directed against God. In treating her harshly and in an uncivil manner, they by extension stand in the way of Christ's reign on earth. In the section where she talks directly to the reader, Trapnel maintains that the Report is not about vindicating herself: "the Lord knows, I would not reach out tongue, hand nor pen, to right my self, or to seek restauration of my loss, I 
wave that, such a thing is below my spirit" ("To the Reader"). In showing that calling her mad or a witch is ultimately wrong, in the same way that calling the prophet Hannah a drunk, Trapnel not only reverses judgment, but is also able to exonerate herself, even though she claims that that is not her aim.

Trapnel does not have to fear any slander and, in the end, does not need to defend herself, as the short statement before she begins her narrative claims: "A Declaration from my own hand shall follow, not being put on by any, save by the great Instructor, who counselleth with his eye, who beareth me out before men and devils. The Lord is on my side, I will not fear men" "To the Reader"). Even though she is the one who writes the Report, God is her instructor and, therefore, the content is irrefutable. Several times throughout the Report, Trapnel makes sure that God is seen as the commander of all of her work, be it her writing or her journey to Cornwall. She describes how she prayed to avoid going to Cornwall, stating that her mind was "so strongly bent against that journey," but that God answered her that he "hath purposed thy going there, and his purpose and counsel shall stand, [...] it pleaseth him, thy going there" (Report and Plea 2). With these words, she fashions herself a prophet who merely obeys God's commands.

As with Julian and Margery before her, Trapnel still, on the one hand, sees the need to justify herself and her writings, and, on the other hand, makes a strong case for herself:

And though I am a poor inferiour, unworthy to be compared with any of the holy men or women reported of in the Scripture; yet I can say with Paul, Through grace I am what I am; and I live, yet not I, but Christ lives in me, and the life that I live, is by the faith of the Son of Cod, who died, and gave himself for a weak hand-maid, as well as for a strong Paul. (Report and Plea "To the Reader")

Here, she calls herself inferior, unworthy, and weak. However, she also states that she has the grace of Christ and that he lives within her. Since her life is lived in accordance with her faith, it must be a worthy life that makes her a worthy person. Unworthiness and weakness are turned into strengths, as in 1 Corinthians 1:27: "But God hath chosen the foolish things of the world to confound the wise; and God hath chosen the weak things of the world to confound the things which are mighty." The suggestion here is that even though she is weak, she will be able to win against the mighty and even though she is called foolish, she deems herself as wiser than the judges and the people who speak against her. She even compares herself to Paul by using the same words 
as he did and by stating that Christ "gave himself for a weak hand-maid, as well as for a strong Paul."

Moreover, calling herself a "weak hand-maid" also emphasises her status as a prophet:

End times will see an increase in men and women prophets: And it shall come to pass afterward, that I will pour out my spirit upon all flesh; and your sons and your daughters shall prophesy, your old men shall dream dreams, your young men shall see visions: And also upon the servants and upon the handmaids in those days will I pour out my spirit. (Joel 2:28-29)

As a Fifth Monarchist, Trapnel clearly sees the end times coming, and it is clear from scripture that God pours out his spirit upon handmaids in these end times. Being a weak handmaid, therefore, makes her the perfect vessel for God and perfectly suitable for writing at his command.

Halfway through her Report, Trapnel summarises the creation of her work in a way that encapsulates God's command to write perfectly and is worth quoting in full:

[F]or in all that was said by me, I was nothing, the Lord put all in my mouth, and told me what I should say, and that from the written word, he put in my memory and mouth: so that I will have nothing ascribed to me, but all honor and praise given to him whose right it is, even to Jehovah, who is the King that lives for ever. I have left out some things that I thought were not so material to be written: and what I have written of this, it's to declare as much as is convenient to take off those falsities and contrary reports that are abroad. (28.2)

She stresses that she is merely a vessel. It is God who puts the words into her mouth and He is also the creator of the written text. Everything that is in her memory comes from Him. Nevertheless, she also admits that she has consciously omitted some things, which she decided were unimportant. In the second part of her statement, she then becomes the creator again by deciding what to write and what to leave out. Even though she maintains that God commanded her to write the Report, Trapnel also wants to write the truth about her journey so as to set the record straight against all the false reports circulating about her. With regard to these false reports, she states: "I don't take delight to stir in such puddles, it's no pleasant work to me; but that truth engageth me to let the world know, what men have acted against the pourings out of the Spirit in a dispensation beyond their understanding" (22). The 
implication here is that the people who write or tell stories about her are not able to judge her since her connection to God is beyond their understanding. In the end, the Report is also written to vindicate her and to portray her as an independent and strong woman who is able to fight for herself and voice her concerns about politics, about how people should live and about what they should believe.

As was the case with Margery and Julian, Trapnel's status as a prophet and a writer becomes a topic in and of itself. True and false prophets are set against each other, using the text as proof that these female visionary writers belong to the few true prophets. In The Cry of a Stone, she says: "They that are thy true Seers shall stand, when they that are false Seers shall fall, and wither, and dye; the true Seers they shall goe on and prosper, thou wilt provide for them sufficient maintenance" (43). The true seers are the ones who need no sustenance because God invests them with spiritual as well as bodily nourishment. As already discussed in the first chapter, Trapnel and Margery report repeatedly that they are weak and sick, only to then suddenly be healthy again. Throughout The Cry of a Stone as well as the Plea, there are several scenes where the weak body and Trapnel's eating habits are described in great detail. During her trances, she does not eat and has to be supported or carried to her bed. However, as soon as the trances cease, she is able to walk again a great distance through London. In all these episodes, she positions herself as a true seer, someone who is commanded by God to write down her experiences for all to read.

Furthermore, as seen in the second chapter, Chidley mobilises her gender as an argument against Edwards' writings. As a woman who is not able to answer him in a scholarly fashion, she denies him any triumph he might have in refuting her writings: "But if you overcome me, your conquest will not be great, for I am a poore worme, and unmeete to deale with you" (Justification 80 ). In the pages before this, she clearly demonstrates that she is able to answer him in a very sophisticated manner. By writing this at the end of her Justification, she undermines any reply from Edwards that comes afterwards. However, she also begins her writings by saying that she is weak and not skilled enough to write. She makes sure that the reader knows that anything that is of weight comes from God and that her answers are "the plaine truth of holy Scripture" (Justification 2). She uses her 'unskillfulness' strategically when answering Edwards for no man would concern himself with indulging such "ungrounded arguments" (A New-Years-Gift "Introduction") only to moments later portray herself as a prophet who speaks the truth through God. 
Like other true prophets, she is "able to unfould the Misteries of the Scripture, (not) by the will of man but by the holy Ghost" (Justification 80). Paradoxically, by using both her unskillfulness and God's testimony in her defence, she is able to legitimise her political views and her writings.

Anne Wentworth (1629/30-1693), a religious writer who wrote prophecies about the nation, her Baptist congregation and her husband, is even more explicit in her call to write usage. Right at the beginning of her True Account, she maintains about her writing: "[I] utterly deny it to be any will of my own, but was commanded of God my Father to declare his goodness, and exalt his name alone, and make his power and Faithfulness known" (5). Throughout the Account, Wentworth denies writing it of her own volition and instead claims that she was commanded by God to write it. Her husband and her congregation, however, believe her to be "deceived, and deluded, and full of notions, whimsies, and self-will" (11) while she criticises them in public. In this Account, we learn how difficult it could have been for women to write and publish their opinions. Indeed, she explains how much she suffered for the book, which was "laid to (her) charge as a great heinous crime" (12). She states:

Now whoever read this, you may understand here is a Book of a weak, foolish, despised womans writing, that sche hath suffered and been persecuted nigh unto death oft and many a time for it, even to the Gates of death, not expecting to live, that its no less than a miracle that I am alive, or in my senses.

It is evident that Wentworth was slandered from all sides, especially by her husband, and was called mad for writing her books. Her writings were even labelled a "heinous crime" and she had to fight against these rumours to restore her credibility in her texts.

In her Vindication, she explains that her husband even seized the texts that God had commanded her to write. Since she is under so much scrutiny, she has to insist that she does not write of her own free will, but that she is commanded by God to write for the good of the nation. At one point in the Vindication, she describes her struggle in more detail, which is worth quoting in full:

And I do further declare, that the things I have published and written, and which are such an offence to my Husband, and indeed the cause of all the Persecutions I have suffered from others, were written sorely against my own natural mind and will; That I often bed'd of Cod I might rather die, then do it. 
That I was commanded of Cod to record them. That my own natural temper was so greatly averse to it, that for eleven months together I withstood the Lord, till by an Angel from Heaven he threatned to kill me, and took away my sleep from me: And then the terrors of the Lord forced me to obey the command. (7)

Here, Wentworth is much more explicit about how she is called upon to write her books than the other visionaries mentioned above. She describes her suffering and how she tried to resist God's command for eleven months. She goes so far as to say that God threatened to kill her, if she did not write. Forced to write the books, she publishes her prophecies against her husband's wishes and those of her congregation for the good of all. She writes about her "unworthyness and nothingness" (12), which paradoxically allows her to stand up to her husband and assert herself as a writer.

\subsection{The Scribe}

Questions of authority and authorship are complicated further by the fact that Margery Kempe and Anna Trapnel's works were written down by scribes and not by the women themselves. Indeed, several of the medieval women's visionary writings are written by scribes, with Liz Herbert McAvoy, for instance, maintaining: "Here, as elsewhere, we are reminded that, even if the impulse towards writing is the woman's own, the ultimate achievement of that design remains dependent on the good-will and endorsement of an appropriate male authority" ("wonderfully turnyng" 106). This suggests that female writers were dependent on men to write the books or at least to legitimise them. However, authorship has had different connotations and meanings across history. Thus the relatively modern notion of authors as single creators, whose works constitute their own intellectual property, does not necessarily apply to the medieval period. Jennifer Summit, for instance, maintains that "the modern idea of the author as a single, creative individual holds limited relevance for medieval textual culture, in which many texts were collaborative, anonymous, or adopted as common property" (91). Just because a woman uses a scribe does not mean that her text gains authority only thanks to the involvement of a male writer. These transcribed texts should be seen as collaborative works that do not diminish the authorship of, for example, Margery, Trapnel or other visionary writers. 
However, Margery's Book is further complicated by having three different scribes, which Rosalyn Voaden comments upon in the following way: "It is obvious that at least three people are writing this book, and none of them is particularly good at it. This lack of skill raises questions about the nature of the collaboration between visionary and scribes, and doubts about the authenticity of the memories in the Book" (113). Through all these different 'voices' in the Book, it seems difficult to know if what is written is authentic or whether what is claimed in the Book is true. Although it was common for women's visionary writings to be written by a scribe, Voaden notes what is different about Margery's Book:

Bridget's female body is written out of the visionary narrative, and she is constructed as voice alone, uttering the unmediated words of Cod. Margery Kempe's Book, attempting to reconcile conflicting discourses, mapping her visionary experiences on to a geography of abusive attention, fails to achieve this effect. (119)

Margery's multiple discourses and voices do not represent the same unified construction of a voice that other visionary writings did.

The different scribes and the Book's writing history are recurrent topics throughout the Book. The reader is told that Margery was asked by various people to write down her revelations and her feelings but she was told by God that she should wait. When God finally commanded her to write down everything, she first had difficulties finding a writer until a man from Germany came to England and agreed to do so. However, this man died and the priest who subsequently agreed to finish the Book could not make any sense of it, calling it "evel wretyn" (46-47). This priest, furthermore, was then influenced by the evil talk about Margery and told her "he cowd not redyn it, wherfor he wold not do it. He wold not, hey seyd, put hym in perel therof" (48). Therefore, he advised her to ask a friend of the first scribe whether he could make sense of the pages. However, this friend was not able to read it either and Margery again was left without a book or a scribe. In addition to all this confusion, she also states that the Book "is not wretyn in ordyr, every thyng aftyr other as it wer don, but lych as the mater cam to the creatur in mend whan it schuld be wretyn, for it was so long er it was retyn that sche had forgetyn the tyme and the ordyr whan thyngys befellyn" (49). Thus, not only is there no structure to the Book, but Margery also tells us that it was such a long time ago that she has forgotten when the revelations happened and in what order. This could cast doubt on "the authenticity of the memories," as Voaden states. If everything 
happened so long ago that Margery has forgotten when and in what order they transpired, then one has to ask what else has been forgotten.

However, in some of the chapters, there are instructions for the reader, which seem to be an attempt to bring order to the Book. At the end of Chapter 16, for instance, we find the following sentence: "(Rede fyrst the xxii chapetre, and than this chapetre aftyr that)" (112). Furthermore, even if the different scribes and the different discourses make one question the authenticity of the Book, I would not necessarily agree with Voaden. The second scribe who "was vexyd in his consciens" (49), ultimately comes back and agrees to write the Book. As mentioned in the first chapter, Margery's gift of crying abundantly for Christ was one of the things that people, including the second scribe, questioned about her credibility. However, when the priest then presents the reader with a list of several other visionary writers who had also cried "wyth lowde voys" (296), such as Elizabeth of Hungary and Marie d'Oignies, this information restores Margery's credibility and the trust of her scribe. Even though Margery's authenticity is in doubt, not only from the scribe, but also from the reader, I would argue that this is just another feature, which in the end legitimises her unique voice. When the second scribe comes back to write the Book, Margery promises to pray to God for him so that he be able to read the pages no one has been able to decipher so far. Trusting in her prayers, the priest is suddenly able to read everything "and so red it ovyr beforn this creatur every word, sche sumtym helpyng where ony difficulte was" (49). This clearly signals that her prayers are powerful and that God wants the Book to be written. It also shows the collaboration that exists between the scribe and Margery. He reads "every word" to her, and she corrects and helps him whenever necessary.

Later, after the scribe starts writing again, his eyes suddenly fail and he cannot write anymore. Even though he is able to see and read everything else, he is not able to write Margery's Book. To this she answers: "hys enmy had envye at hys good dede and wold lett hym yf he mygth, and bad hym do as wel as Gold wold yeve hym grace and not levyn. Whan he cam ageyn to hys booke, he myth se as wel, hym thowt, as evyr he dede befor" (50). The priest cannot read and write the book anymore because the enemy is envious of the good work being done. But suddenly, through God's grace (and Margery), he is able to see and write again. It seems like all the problems Margery faces in writing her Book are there only to show that she has God's grace and is a true prophet. All the different scribes are there to establish her authority, as are God and the people she encounters throughout the Book. Even the lack of 
structure and the plurality of discourses add to her trustworthiness. We are shown the life, as well as feelings, of a prophet which cannot be structured as a book. The scribes do not include anything that could lend the episodes greater order or a unifying theme so as not to add anything which is not true. "And therfor sche ded no thing wryten but that sche knw rygth wel for very trewth" (49). Nothing but the truth is written and Margery's unique voice can be heard throughout the Book, without any distortion from the scribes.

In the case of Anna Trapnel, the fact that she is in a state of trance and does not know what she is uttering means that we need to rely on the scribe's record and therefore she is even further removed from authorship. In addition, the scribe is not a completely reliable source. As he himself says:

The things she delivered during this time were many; the four first days no account can be given, there being none that noted down what was spoken. For the rest of the time, from the fifth day to the last, some taste is herein presented of the things that were spoken, as they could be taken by a slow and imperfect hand. (The Cry of a Stone 2)

Hence, not everything has been written down and, from the days for which he has taken notes, he is only able to give us a taste. Interrupting Trapnel's account several times, the scribe explains time and again that he failed to write down "many precious things" because of "the press of people" or that he only "could take them in some scattered expressions" (The Cry of a Stone 35). He is not able to write down most of the songs and, in general, maintains that he could really only record bits and pieces. Indeed, in most of the introductory comments, he writes: "Having with these uttered many other things [...] which escaped the Relators pen, by reason of the lownesse of her voice, and the noise of the people; only some pieces were taken here and there, but too broken and imperfect to relate" (The Cry of a Stone 58). The implication is that much more is said and sung by Trapnel and the choices regarding what to include and to leave out seem to be made by the scribe rather than the prophet herself.

At one point, he even declares that " $\mathrm{t}] \mathrm{h}$ he foure last words of the last Verse are added by the Relator, who could not take the Maids owne words, her voyce as it were dying, and sinking into her breast, with which she closed for that time" (The Cry of a Stone 45). Not only is the report incomplete, the scribe even changes or adds his own words to the utterances he notes down. The interesting thing is that Trapnel could have written Cry herself by relying on her visions and the evidence of the witnesses. After all, it is clear from the Report and Plea that she is able to write, but she chooses not to do it. In acting as a 
witness, the scribe, even in his unreliable nature, adds another layer of authorisation to the account. He believes in Trapnel and, through him, the reader is able to learn what he witnessed, to experience the immediacy of being close to a prophet, which otherwise the work would not have had. It is as if we, too, are in the room with the scribe, listening to Trapnel's utterances while people are bustling about hoping to stand witness themselves. The scribe describes the room, mentions the numerous people who come to visit Trapnel, and is able to depict her as a true prophet. By explaining that his transcription could not be complete because of the many people in the room or because of Trapnel's way of delivering the prayers and songs, he also gives credence to her trances. This demonstrates that many people are interested in hearing her, as the room is always full of people, some of them even mentioned by name. The importance of some of these people has already been touched upon in the second chapter, validating the political impact of Trapnel's revelations as well as the significance of her utterances as prophetical declarations.

The difficulty to transcribe Trapnel's exact words is attributed to the prophetical nature of these utterances. She is God's mouthpiece and her outbursts are a direct representation of this bond. The scribe, for instance, comments more than once on the way she delivers her prophecy. She sings and prays in a language that the scribe is not able to repeat because the words are "much more largely then the Relator did, or could take them from her" (The Cry of a Stone 45). He also describes her deliverance in the following way: "Here she seemed to have over-flowings of joy and delight in spirit, and poured out her heart in a Song" (The Cry of a Stone 48). The scribe's failure to record everything does not reflect negatively on the truthfulness of Trapnel's revelations, it proves exactly the opposite. Her "over-flowings of joy and delight" and the "large" words that she utters come directly from God and are, thus, impossible for the scribe to accurately convey.

In an introductory epistle right at the beginning of the Cry, Trapnel's status as a prophet becomes a topic in its own right.

It is hoped in this day, a day of the Power of Cod, a day of wonders, of shaking the heavens and the earth, and of general expectation of the approachings of the Lord to his Temple, that any thing that pretends to be a Witness, a Voice, or a Message from Cod to this Nation, shall not be held unworthy the hearing and consideration of any, because it is administred by a simple and unlikely hand. 
The point being made here is that although the account has been written by "a simple and unlikely hand" the message comes from God and is of great importance and for all to hear. This is especially true when it is a prophecy that speaks of and facilitates the imminent Kingdom of Christ on earth. This, of course, adds a political dimension to the Fifth Monarchist movement and Trapnel's, as well as the scribe's, beliefs and involvement in the group. Apart from this political statement, Trapnel's status as a prophet is established and defended here. Just as in the Report and Plea, witchcraft and madness are only two of the many accusations that she has to deal with after her utterances. Thus, the epistle states:

If any may be offended at her Songs, of such it is demanded, If they know what it is to be filled with the Spirit, to be in the Mount with Cod, to be gathered up into the visions of God, then may they judge her; until then, let them wait in silence, and not judge in a matter that is above them. (The Cry of a Stone)

The implication here is that only those who have also received visions from God are able to judge Trapnel, which is to say that most of her opponents cannot say anything against her, as the "matter [...] is above them." Trapnel voices the truth, because of the bond between her and God, which is underlined by the scribe's witnessing of the prophecies.

Both the scribe and Trapnel are cognisant of the fact that her opponents will call her mad or a witch, which is why, just like in Report and Plea, the epistle concentrates on the authenticity of the account to help counter the accusations:

There being various reports gone abroad concerning this Maid, too many being such as were not according to truth, whereby it comes to pass that the things she spake, do not appear to men as they cam from her, but as deformed and disguised with pervertings and depravings of the Reporters, therefore it was upon the heart of some that heard her [...] to present to publick view a true and faithful Relation of so much as for some 7 or 8 dayes could be taken from her. (The Cry of a Stone)

The accusations against Trapnel are caused only by the untruthful accounts circulating about her. It is the reporters of these accounts who distort her visions and are, thus, responsible for any misunderstandings and false statements that she is being condemned for in the first place. The Cry of a Stone is, therefore, the result of the combined wish of the many listeners that came to 
visit Trapnel to "present to publick view" the truth, which nobody will be able to judge. This lends credibility not only to this account but to her prophecies in general. This is the only accurate account of her utterances in White Hall, containing the words of God spoken through Trapnel.

To legitimise the revelations even further, the scribe presents a first-hand account by Trapnel at the beginning of the Cry in order to answer all questions and assuage all doubts that might arise about her credibility: "touching the condition of the Party, where? or what she is? to whom is she known? is she under Ordinances? what hath been her conversation formerly?" (2). Personal information about Trapnel, her relations, and where she comes from are of great importance in establishing her as a prophet. The next page opens, therefore, in the following way:

I am Anna Trapnel, the daughter of William Trapnel, Shipwright, who lived in Poplar, in Stepney Parish; my father and mother living and dying in the profession of the Lord Jesus; my mother died nine years ago, the last words she uttered upon her death-bed, where these to the Lord for her daughter. Lord! Double thy spirit upon my child; These words she uttered with much eagerness three times, and spoke no more. (The Cry of a Stone 3)

The account here switches to a first person narrative. Trapnel states her name as well as those of her parents and the profession of her father. Her mother, however, seems to be of even more importance as she is the one who, with her dying words, asks Christ to "double" his spirit on Anna. This account, then, not only changes to a first person narrative, it also shows that Trapnel provides the scribe with her personal history. We detect here signs of a clear collaboration between Trapnel and her scribe, making The Cry of a Stone effectively her work and words.

In the subsequent paragraphs, Trapnel, furthermore, establishes herself in her community, listing the church meetings at All Hallows in London with John Simpson, Mr. Greenhill, Henry Jessey, Mr. Venning and Mr. Knollys, all of whom "have knowledge of me, and of my conversation; If any desire to be satisfied of it, they can give testimony of me, and of my walking in times past" (The Cry of a Stone 3). The testimony of these important figures demonstrates her position in the Fifth Monarchist movement. Knollys, a Particular Baptist and Fifth Monarchist, for instance, became a member of Henry Jessey's congregation in 1644 (Knewport), while Jessey, a nonconformist minister, was friends with Simpson and a lecturer at All Hallows (Wright). With regard to 
Simpson, it is said that after serving as a major in the campaign against the Scots' invasion in 1651,

he joined Christopher Feake in calling a meeting at All Hallows to rally support for the millenarian cause. It was here that the Fifth Monarchist movement was born, with All Hallows its centre and Feake and Simpson its first leaders. Unlike many radicals, Simpson placed no trust in Oliver Cromwell as the instrument of Cod. (Capp)

Trapnel has testimonies from all these leaders of the Fifth Monarchist movement, closely connecting her to All Hallows and to the political stances of the millenarians that were touched upon in the second chapter. All of these very important testimonies firmly confirm her background and lend her credibility as a prophet rather than a madwoman. After her validation as a member of the Fifth Monarchist movement, the reader learns that her mother's dying wish has come true. Trapnel begins her rite of passage to becoming a prophet through her illness, from which she is then delivered by God. Her subsequent visions about the Battle of Dunbar and Cromwell's appearance firmly establish her credibility as a prophet.

After this first person account, the scribe interrupts again to include the visions Trapnel had in White Hall, and adds his own questions to her to help authenticate her trance-induced revelations. He, for instance, asks her: "was it Vision wrapping up your outward senses in trances, so that you had not your senses free to see, nor hear, nor take notice of the People present?" (The Cry of a Stone 14). Her answer, of course, was that she neither saw nor heard anything except the voice of God, to which the scribe adds:

besides her own word, the effects of a spirit caught up in the Visions of Cod, did abundantly appear in the fixedness, and immoveableness of her speech in prayer, but more especially in her songs, nothwithstanding the distractions among the people - which was observed by many who heard her, who seemed to us to be as one whose ears and eyes were locked up. (The Cry of a Stone 14)

His descriptions of Trapnel's body and movements, as well as him mentioning everyone present and witness to these visions serve to establish her authority as a prophet. Here, the collaboration between Trapnel and the scribe becomes apparent through their dialogue. It shows that she has a hand in the writing of the Cry and that she would have been able to change the account if she had wished to do so. Even though the scribe excuses himself for being simple and 
slow, his interruptions and descriptions, in addition to Trapnel's own account of her becoming a prophet, contribute to authenticating both the visions and Trapnel herself.

\subsection{The Vessel and the Mouthpiece}

Authorisation is further complicated through the self-effacing disclaimers these female visionary writers make about the content of their prophecies. In addition to their claims that they would not have dared to write their books, if God had not commanded them to, and their use for scribes in some of their writings, most female visionaries surrender the content of their books completely to God. They depict themselves merely as vessels or instruments of God who only repeat God's words. Thus, self-effacement is involved not only when it comes to writing the books, it also shapes female speech and the whole content of the books. ${ }^{1}$ In Margery's case, the dialogues between her and Christ or God belong to the most prominent features in the text. Once she is established as a prophet, meaning after the reader has been told about her background and personal history and the illness from which God delivered her, Christ starts talking to her, asking her to "thynk swych thowtys as I wyl putt in this mend [...] and I schal yefe to the hey medytacyon and very contemplacyon" (73). As commanded by God, Margery writes about her life, her feelings, and her revelations that come from God rather than from herself. Furthermore, Christ is the one who places thoughts into her mind. Thus, she only acts as a mouthpiece in everything she says, thinks and does. At one point, the Lord not only turns her into a mouthpiece, he even exchanges places with her: "For thei that worshep the, thei worshep me; thei that despysyn the, thei despysn me, and I schal chstysen hem therfor. I am in the, and thow in me. And thei that heryn the, thei heryn the voice of God" (85). When she speaks, we hear the voice of God and everything that is done to her is also done to Him. If people despise her, they despise Him. He even gives permission to worship

In many of these books the line between speech and writing is very much blurred. Large parts of Margery's Book, for instance, consist of direct speech between her and Christ. The lack of order and structure, give the Book an immediacy that can be attributed to speech. In the Cry of a Stone, the representation of Trapnel's direct utterances is also a written testimony of speech. The written representation of a prophecy, which is closely connected to speech, becomes a feature integral to the process of authorisation established in these chapters. 
her, claiming that it is the same as if He is being worshipped. Thus, Margery is much more than only a voice.

Given the use of direct speech in the text, the reader can still see a clear distinction between Margery and Christ's voice. We can hear the conversation between the two and we, especially, hear the uniqueness of her voice. Even though she constantly expresses her doubts about her status as a prophet due to her sinfulness and unworthiness, Christ continues to confirm her status as divinely inspired. As a result, Margery's authority is repeatedly re-established throughout the Book. Christ's answers to her doubts add to the uniqueness of her voice and the special status she has in His eyes. Although she was a business woman for part of her life and bore fourteen children, she is depicted as though she has been perfect all her life. At one point, she tells Christ that she wants to dance with the virgins in heaven and that "lak of maydenhed is to (her) now gret sorwe" (135). She also mentions that she regrets that she had not loved the Lord all her life. In spite of these flaws, Christ reassures her:

Thu art to me a synguler lofe, dowtyr, and therfor I behote the thu schalt have a syngular grace in hevyn ... Dowtyr, whan thu art in hevyn, thu schalt mown askyn what thu wylt, and I schal grawnte the al thi desyr. I have telde the befortyme that thu art a synguler lover, and therfor thu schalt have a synguler love in hevyn, a synguler reward, and a synguler worshep. (135-138)

The word "synguler" is repeated six times within these few pages. Margery is singular in her love of Christ but also singularly loved by Him. What is more, she has such grace that she can wish for anything she wants and He will grant it. In the same conversation He also tells her: "so schalt thu dawnsyn in hevyn wyth other holy maydens and virgynes, for I may clepyn the dere abowte and myn owyn derworthy derlyng" (138). It seems like Margery will be able to dance with the virgins in heaven, even though she is a mother of fourteen children. Not only is her authority established, she is also singled out as especially loved by Christ and able to wish for whatever she wants, thereby gaining a status otherwise only given to saints or virgins.

And Margery does have several wishes. As we saw in the second chapter, she receives a signed letter, which allows her to travel throughout the country. She also has another letter giving her the right to choose her own confessor and receive communion every Sunday. Furthermore, she also goes on pilgrimages without any money and she asks Christ to let her see all the important sites, such as Jerusalem, Rome, and Santiago de Compostela, with her own eyes, and her wish is granted. At one point, there is a great fire in 
Bishop's Lynn, threatening to destroy the church and other parts of the town. So Margery, who is there at the time, begins to pray: "Good Lord, make it wel, and sende down sum reyn er sum wedyr that may thorw thi mercy qwenchyn this fyer and esyn myn hert" (308). When the sparks begin to enter the church and all seems lost, three men come into the church saying: "Lo, Margery, God hath wrowt gret grace for us and sent us a fayr snowe to qwenchyn wyth the fyr" (308). Her prayers have been heard and God works a miracle to save the town and the church. It appears that it is not just the Creator that deserves to be thanked here but also Margery. As the priest states: "he belevyd that God grawntyd hem for hir preyerys to be delyveryd owt of her gret perellys" (308). Had it not been for her and had her wish to perform miracles not been granted, the fire would not have been extinguished.

Many of her wishes are also rather worldly. She often asks God about the lives of people around her, wishing to know their fate and their faith. This stands in stark contrast to Julian who asks God a similar question about a friend but does not receive an answer. Indeed, as already mentioned, Julian removes most of the personal material from the Long Text, such as information about her mother and her own story. Instead, she only includes that one episode about her friend, of whom she wants to know whether he or she will continue in "good levyng" (48). The answer to her query is the following:

And in this syngular desyer it semyd that I lettyd my selfe, for I was nott taught in thy tyme. And then was I answeryd in my reson, as it were by a fendulle mene, 'Take it generally and beholde the curtesy of thy Lorde God as he whewyd to the, for it is more worshype to Cod to beholde hym in alle than in any specyalle thyng.' (48)

The implication, here, is that asking God to satisfy her personal curiosities is selfish and that Julian would do better to learn about God, in general, than concern herself with such trivial things. She should not concern herself with these earthly matters and instead concentrate on her revelations, which are of much greater significance and scale as they deal with matters of sin, salvation, and the greater humanity. This is a possible reason for why she decided to exclude most personal information from the Long Text. Her persona should be seen as unimportant, which is meant to lend her voice more authority when talking about her rather subversive theodicy and the political interpretation of her revelations.

Margery's approach, however, is the complete opposite. She, for instance, asks Christ to have mercy on a "wykkyd woman," who was on the point of 
death: 'Lord, as thu lovyst me, save hir sowle fro dampnacyon,' [...] And owyr Lord grawntyd hir mercy for the sowle" (139). She also asks about a good friend who was very ill and Christ tells her: "Dodwtyr, be not abaschyd for this man, he schal levyn and faryn wygth wel" (140). Throughout the Book, there are many instances such as these, where Margery uses her bond to Christ and her role as his instrument to her advantage. In more then one instance He tells her that He will fulfil all of her wishes and desires and she seems to take these statements quite literally. She is even able to choose someone who will be her companion in heaven. When she wishes for her spiritual father, Master $R$, to be her companion, Christ asks why she would not choose her own father or her husband to be with her in heaven. However, He also assures her: "I graunt the thi desyr of hym, and yet schal thi fadyr ben savyd, and thi husbond also, and alle thi chylderyn [...] Dowtyr, I schal be a trew executor to the and fulfyllyn all thi wylle" (81). All of her wishes are granted. All she has to do is ask and Christ fulfils her wishes. Sometimes she is even granted privileges she has not asked for.

At one point, she asks for a priest to give a sermon to her every day and Christ answers: "Ther schal come on fro fer that schal fulfillyn thi desyr" (279). This same priest then reads many books to her, including "Bonaventur, Stimulus Amoris [and] Incendium Amoris" (280). As mentioned in the first chapter, these books are of great importance to Margery, since she models herself after their authors and tries to outdo them even so as to demonstrate her piety and her special status as a prophet. It is interesting how the Book tries to argue that it is the priest who benefits from Margery, not the other way around: "for he fond gret gostly comfort in hir and cawsyd him to lokyn meche good scriptur and many a good doctowr, whech he wolde not a lokyd at that tyme, had sche ne be" (279-280). It seems like she asks the priest specifically for these books and that had it not been for her, he would not have read them. Additionally the priest receives spiritual comfort from Margery, turning her into a priestess herself. Thus, she gains authority not only by being able to wish for anything she wants, but also through the fact that she can bestow spiritual comfort and leadership onto others.

What transpires is that Margery's way of life and revelations are superior to what the priests can preach. This is first made clear in the second chapter, when she is able to rebuff all the questions the clergy ask of her and clear her name of all accusations of heresy, and it becomes even clearer in a later episode, in which her love and wishes are again the topic of conversation between her and Christ. After Christ promises that, if she obeys His will, He will 
fulfil hers, He states: "Ther is no clerk can spekyn ayens the lyfe whech I teche the; and yyf he do, he is not Goddys clerk, he is the develys clerk" (301). In other words, if any clerk should speak up against her, he is the devil's clerk. When she suggests that God should teach priests and other religious men the same way of life He has taught her, He answers that this is not possible because "undyr the abyte of holynes is curyd meche wykkydnes" (302). God assures Margery that He does not teach priests and other religious men what He has shown to her because there is much wickedness under the habit of holiness. This rather bold statement gives Margery authority over the clergy as she is shown to be holier than the priests. Interestingly, as the conversation proceeds, God also explains that there will come a time when all these men will believe in her grace and believe in Margery herself. Those who still do not believe, He "schal chastisyn hem as it wer for myself" (302). To which Margery answers: "Nay, derworthy Lord Jhesu, chastise no creatur for me" (302). Margery explains that she does not want chastising men, and asks for mercy and grace for all men. God assures that He will "spar for thy lofe" (302). Though Margery is careful in her wording ("yyf it be thy wille to grawnt it" (302)), the roles seem almost reversed. She is the one able to spare the wicked. Her love for her "evyn-Christen" (303) saves them and her authority over her community reaches its peak here, becoming almost God-like.

In addition, although Margery uses the conventional strategies of selfeffacement and of claiming to have been commanded by God to write, she goes far beyond them to assert her authority in the dialogues between her and the Lord. She clearly uses her intimate relationship and her status as a singular inspired woman to her own end. Margery's voice and desires are made evident in chapter eleven, where she goes as far as bargaining with Christ. In this chapter, she and her husband talk about her chastity, which is very important for her to keep. Her husband only agrees to live a chaste life if Margery grants him three wishes: the first is that they still lie in a bed together, the second is that she pays his debts before going on pilgrimage and the third is that she breaks her fasting on Fridays. The third wish poses a problem, as fasting on Fridays is a divine order Margery cannot break. She then starts bargaining with God and tells Him in no ambiguous terms: "For yyf I wold brekyn that maner of fastyng whech thow comawndyst me to kepyn on the Fryday wythowtyn mete or drynk, I schuld now han my desyr" (88). She states her wishes boldly against God's command. His answer, however, is even more surprising: "For, my derworthy dowtyr, this was the cawse that I bad the fastyn, for thu schuldyst the sonar opteyn and getyn thi desyr, and now it is 
grawntyd the" (89). God's answer that he only commanded her to fast so that she would have something to bargain for reads like a rather clever gesture of self-authorisation on Margery's part.

In terms of authorship and authorisation, Trapnel's The Cry of a Stone and her Report and Plea are also quite intricate and complex. On one level, The Cry of a Stone is a prophecy, meaning that Trapnel is expressing God's will. Rather than her own voice, we are supposed to hear the voice of God through her. Diane Purkiss explains that a "prophetic utterance necessarily involves a radical dislocation of the voice from the body, since in authentic prophecy the voice comes from God, while the body through which it speaks is a passive conduit" (141). This gives Trapnel the best possible claim on authorisation because it means that everything she says, including the politically controversial topics, do not originate in her but come directly from God. She is protected through the mode of prophecy and since it comes from God, she necessarily speaks the truth. On the other hand, the question remains as to whether Trapnel can be seen as the author of The Cry of a Stone or the Report and Plea given that their writing has been commanded by God, and she is only an instrument and a mouthpiece of God's words. However, the loss of one's own voice and even of the self in favour of the ultimate authority is one of the most dominant features of women's visionary writings. With regard to Trapnel, Sue Wiseman, thus, states: "Her voice expresses a message from God. Authority for speech here is returned to the ultimate source and origin of all things" (187). In order to gain this authority, Trapnel repeatedly asserts that she is nothing, merely an instrument and a vessel to the will of God.

Phrases such as "I was nothing" and "I was a simple creature, onely divine wisdome was pleased to make use of the simple, and to call them to him, to shew them his love, to chuse such to do him service" (Report and Plea 28.2) are repeated throughout her works. "Trapnel presents herself [...] as quite passive, scarcely conscious or in control of what she says. This is a notion which recurs frequently in seventeenth-century prophetic writing: the prophet operates by abandoning control of the self to God" (Chedgzoy 243). ${ }^{2}$ This can be seen, for instance, in the episode in which Trapnel needs to answer before the judge. As seen in the second chapter, she is able to answer all of his questions and even reverses their roles. In addition, she also uses the interrogation to prove that she is not a witch since witches would not be able to answer a judge. 
As further evidence of her authority, she cites conversations with people whom she meets on her journey to Cornwall and back when she insists on not having the answers herself but on God giving her the words: "many people spake much to me, asking me questions, the which the Lord helped me to answer" (Report and Plea 22). To explain how the Lord helped her answer, she states:

"Take no heed what thou shalt say; being brought before them for the Lord Christ's sake, he will give thee words: dost thou know what they will ask thee? Therefore look to the Lord, who will give thee answers suitable to what shall be required of thee [...]" And this I thought, I would be nothing, the Lord should have all the praise, it being his due. (Report and Plea 23)

Again, she claims that she is nothing and that everything she says comes from God rather than from herself. He provides the answers in all situations, giving her the right words for judges or people whom she meets on her journey. The ability to have the right answer in each situation helps her to prove to people that she indeed is a prophet and a mouthpiece of God.

On the one hand, the complete debasement of her self and the loss of her own voice seem to contradict a powerful self-authorisation of her as an author. On the other hand, however, as an instrument of God, she has great power. As He says to her: "I will make thee an Instrument of much more; for particular souls shall not only have benefit by thee, but the universality of Saints shall have discoveries of God through thee" (The Cry of a Stone 3). Through Trapnel, her writings and her voice, people benefit and learn of God. She, thus, has the power of the path of salvation, giving the people around her the possibility to hear God and follow the right path. This paradox of having a voice, but also having God's voice is perfectly expressed in The Cry of a Stone: "Oh, it is for thy sake, and for thy servants sakes, that thy Servant is made a voyce, a sound, it is a voyce within a voyce, anothers voyce, even thy voyce through her" (42). It is a voice within a voice and a voice that speaks through her. Her voice and God's voice through her give her the necessary proof that what she says is the truth, no matter what she expresses. It is difficult to say then which is her voice and which belongs to God. This duplicity acts as a powerful source of authority, investing her with the power needed to speak about politics and religion, which would otherwise not be possible.

Thus, she portrays herself as a true prophet, who has insights from God that only she can know. Similar to comparing herself to a weak handmaid, who is the perfect vessel of God, she also voices the following: 
I was a simple creature, onely divine wisdome was pleased to make use of the simple [...] I am a poore sorry reed, but divine power, and the wind that Christ told Nichodemus, in the 3. of John the $8 .^{3}$ which bloweth where it listeth, that wind said $\mathrm{I}$, hath taken a silly creature, and hat made her understand its sound, that which Nichodemus a great Rabbi, could not tell what to make of. (Report and Plea 28.2)

Once again, Trapnel insists that she is a "simple creature" and a "poore sorry reed." At the same time, she claims she is the one who understands the wind that not even Nicodemus could understand. In contrast to this "great Rabbi," she is spiritually reborn and has a direct connection to God. He speaks to her and she understands everything that He says. She is, thus, a true prophet. Indeed, throughout the Report and in the Cry, it is of great importance to Trapnel to vindicate herself and make sure that everything said against her is not only exposed as false but understood as an attack against God. In the end, it is Trapnel who chooses what to say and what not. She is the final authority over her own words even though she claims otherwise. As we have seen above, she chooses to include some things in her Report but not everything. In the conclusion of the text she states: "I shall begin to shorten my relation, least I should be too tedious to the Reader, and leave the Visions and opening of Scriptures that the Lord brought to my soul, while I was in Bridwell for my own benefit" (Report and Plea 45). She does not want to be "too tedious" by keeping on writing, but she also wants to make sure that the reader knows she has had many more visions from God, which she chooses to leave out for her "own benefit." Even though her voice is not her own and she can be seen as rather passive, as Chedgzoy maintains, we can hear Trapnel clearly in several instances. She is at once invested with authority from God by acting as His mouthpiece and she is able to wield this authority for her own interests.

In Anne Wentworth's case, as we have seen in the beginning of the chapter, it is also God forcing her to write the texts. She writes that she resisted this command as long as she could until God threatened to kill her. Like the other female visionaries, she also portrays herself as a vessel and a mouthpiece of divine intention:

John 3:8-10: "The wind bloweth where it listeth, and thou hearest the sound thereof, but canst not tell wence it cometh, and wither it goeth [...] Nicodemus answered and said unto him, How can these things be? Jesus answered and said unto him, Art thou a master of Israel, and knowest not these things?" 
My God who has been so many years Emptying me from Vessel to Vessel, breaking me all to pieces in myself, and making me to become as nothing before him; and who has by many and great Tribulations been bowing my own will, and fitting me for his service, and who having taught me to tremble at his word, has thereby call'd and commanded me into his work. (Vindication 3)

She seems to have been broken into pieces by God and then rebuilt again. Indeed, her whole persona is reduced to nothing but a vessel for God. Like a reed, she bows to his will and only does his bidding. At several points, she calls herself a "weak instrument" (Vindication 9) and makes sure that nothing she writes or says can be seen as coming from herself: "But I have renounced my self, and laid down my own wisdom and will in this work, and am given up to all the will of God herein" (Vindication 9). As with the other women discussed here, Wentworth portrays herself as a mouthpiece without any thoughts of her own. The implication is that nothing in her writings reflects her own opinions. She is but a messenger of God, helping the world to see the truth.

Though Wentworth seems to be giving up any individual sense of authority, the whole content of her texts revolves around her person. In Vindication, as well as in True Account, she legitimises herself not only by claiming to be a strong, individual woman, but also a single woman separated from her husband. At the beginning of True Account, after stating that she is nothing but a vessel for God's words, she also frames her intent in the following way:

and I must confess all the cause I gave, and what I have done, and how this war begun, and how it came to rise so high, and grow so hot, that it cannot be ended or taken up in private, but must come into the open field of the World to be tryed and fought out, and all see whether truth or men be strongest, and which the Victory got. (True Account 5)

This, in a nutshell, captures Wentworth's intention to write. Interestingly, in the beginning of her statement, she uses the word "confess." The confession in question, normally given in private, happens to be public, as is the entire content of her texts. She openly discusses the war with her husband concerning his mistreatment of her during their long marriage and her ultimate separation from him. This conflict with him and their fellow church members is laid bare in the texts, although she acknowledges it should ideally be "taken up in private." Because she knows that the content of her texts is highly delicate and distinctly personal, she feels the need to justify making this public confession. 
At various points, she talks of the ill treatment she received from her husband and their fellow church members, who would call her mad and try to prevent her from writing. She maintains that

[they] have declared me an Heathen, and a Publican for matters of Conscience, in which I was faithful to the Teachings of Cod, according to the Scriptures of Truth, and obey'd the voyce of the Lord, who called me out from amongst them, that I might not partake of those Terrible Plagues, and dreadful judgments which are coming upon all Formalists, Hyppocrites, and profane Persons, who are all of them the Inhabitants of this Earth. (Vindication 1)

Here, she is called a heathen by her husband and their congregation in order to defuse the impact of her words and her texts. She further explains:

And yet I also judge it is the mistaken and rotten Interest of my Adversaries, not only to report, but to believe me a person beside my self: for if I be sound in a right mind, how Mad must they be discovered to have been, in their blind rage and fury against me and my Testimony. (Vindication 8)

Apart from being called a heathen, Wentworth is also labelled mad. As she states herself, they only call her that, because it is in their interest to represent her as being mad, as, otherwise, they would have to recognise her prophetic authority. She thus turns their slander upside down, reducing it merely to a rhetorical device that disguises their false beliefs. But she assures the reader that she is the one who is "faithful to the Teachings of God" and speaks the truth of scripture. As a prophet and mouthpiece of God, she proves to be the one who is chosen by God to tell the truth, which, interestingly, includes her own personal story about her marriage and the ill treatment she had to endure from her husband.

Furthermore, she not only wants to justify or vindicate herself, but she also prophesises the punishment of her husband and anybody who makes slanderous comments against her. The quote above hints at the "dreadful judgment" that is in store for hypocrites and profane people. Occasionally she is even more specific, mentioning the punishment in store against her husband and her congregation, the reason for which she summarises in Vindication in the following way:

Full eighteen years with grief consum'd, and to the Grave bow'd down, Because the Lord have rais'd me up, 
to make his power known

and bad me shew his wonderous works,

And glorifie his Name.

[...]

Disprove me plainly if you can,

Before the next New Year.

For after that, great wrath expect,

which on those will burn as fuel,

Who their fellow creature were

Not merciful, but cruel

[...]

O God arise, make hast to judge

between my Foes and me,

O stop their mouths, clear me, and let

but guilty ones go free. (Vindication p. 19-20)

For more than eighteen years, she endures her marriage. But now God is asking that her story becomes known by everyone to glorify His name, and to free Wentworth from her husband and her congregation. As a prophet of God, she warns that her enemies will only have time to disprove her until the New Year. After that, God's wrath will come down upon them, proving that Wentworth was right all along. God will make the truth known and her husband's attempt to silence her will become his downfall.

Furthermore, she turns her husband's accusation of her being a heathen on its head. Even though she does not exactly say anything unkind about him, she makes it clear that he is not born again and thus does not belong to the chosen few. She describes him as an honest man, who has the "gift of his tongue," making him the ideal businessman and fit for "employment in this world" (True Account 11). However, even though she calls him honest, she also states that he is a man of the world, which stands in stark contrast to her own service to God. In contrast, all of her husband's honesty does not make him fit for true service in the name of God since he only concentrates on worldly matters. She maintains that she does not know of any "gross sin that he is addicted to," but, on the other hand, she describes him as selfish and known "to satisfy himself in all his own will, without being born again; for I dare be bold to affirm that he never yet knew the new birth, the life of the new man" (True Account 7). Like Trapnel, when she talks about Nicodemus in the above cited passage, Wentworth and her congregation believe that one has to be 
born again in order to belong to the chosen few, which is why she claims she is "a true child of God, born from above [...] except we be born again we cannot enter into the Kingdom of God" (True Account 1). ${ }^{4}$ Hence as her husband is not born again, his words and everything he says against her cannot be taken as the truth. Unlike his wife, he is not "a true child of God."

Wentworth's ingenuity is to counter her husband's accusations with scripture. Everything that she had written before had been destroyed by her spouse and her leaving him is the reason for writing these texts. At the beginning of True Account and at various other points, she explains her dilemma of not wanting to write or say anything against her husband and the congregation but being commanded by God to do so. It is of utmost importance for her that we understand that she is the vessel of God. This allows her to counter the slander by pointing out that, as a vessel of God, she can only speak the truth: "Yet the Lord would have me speak the truth, and the more they dashed at it, and beat the poor weak instrument for it, the more the Lord of Life, who was the Agent, confirms it, and in the close now gives his reasons why he would have this work done" (True Account 6). Her work is God's work and the more slander she has to endure, the more the truth will be known and the more severe God's wrath and punishment will be.

Wentworth also uses scripture to refute her husband's claim about her being a heathen by making several analogies between herself and biblical figures. For instance, she maintains: "For they might as well accused Abigail for saying her Husband was a churlish Nabal, and folly was with him, ${ }^{5}$ and have reproved Moses for writing that King Pharaoh was an opressing King" (True Account 11-12). Abigail, who is "a woman of good understanding," has the same right to refer to her husband as churlish as Wentworth has to write about her husband's abusive treatment during their marriage. She also compares herself to Moses, justifying her writings about the oppression of her husband. Through figures such as Moses and Abigail, as well as the ultimate authority, God, she argues convincingly for her essentially private life in a public forum

John 3:4-7: "Nicodemus saith unto him, How can a man be born when he is old? can he enter the second time into his mother's womb, and be born? Jesus answered, Verily, verily, I say unto thee, Except a man be born of water and of the Spirit, he cannot enter into the kingdom of God. That which is born of the flesh is flesh; and that which is born of the Spirit is spirit. Marvel not that I said unto thee, Ye must be born again." 1 Sam 25:3: "Now the name of the man was Nabal; and the name of his wife Abigail: and she was a woman of good understanding, and of a beautiful countenance: but the man was churlish and evil in his doings; and he was of the house of Caleb." 
against her oppressive marriage, vindicating her reputation and asserting her autonomy. The confidence she gathers by such means is reflected in the conclusion to her writing: "And though it begun in much weakness, yet it will end in full strength, that the evil one shall not be able to overcome, for a child is not a man as soon as he is born" (True Account 13). Even though her husband might have destroyed most of her previous writings, Wentworth learns to argue and structure her texts anew as a result. Just as a child needs time to learn and perfect different skills in growing up, so, too, does Wentworth refine her writing to a point where her husband is not able to destroy or refute it anymore. Though she might have been weak and dependent at the start, she ends her text "in full strength," having fashioned a confident, powerful, and independent woman with the help of her writing.

Since they are aware of the cultural restrictions against them, such as the edict in Paul's writings that women ought to be silent, should not participate in political discussions, and are not allowed to teach, all of these women go to great lengths to prove that they have been commanded by God to write. All of these female visionary writers begin their texts by commenting on their shortcomings, their weaknesses and their nothingness. While giving into these negative stereotypes seems to contradict any type of authority or authorship these women might have, they manage to use these cultural restrictions in their favour. By ostensibly conceding authorship and their own voice, they are able to do exactly the opposite, namely to produce texts, participate in political discussions and make their voices heard in a public space, which would otherwise not be available to them. As God's vessels, they gain an authority nobody is able to refute, which provides them with an opportunity to make their thoughts known and tell their personal story.

Julian, for instance, begins by claiming that she is a "woman, ignorant, weak and frail" and she is very careful to counter any notions of her being a teacher. But at the same time she insists that she is the only one to have received these revelations, which are beneficial to all Christians and which need to be published by God's command. There is no intermediary between her and God, no priest who needs to translate or make sure it conforms with the Church's teachings. Thus, many of the revelations are subversive, such as Julian's salvation theory and her treatment of the imago dei. Even though she is commanded by God to write and revelations are shown to her, we also hear her unique voice on religious and political matters. In Margery's case, it is not only God who gives testimony to her writings, but also Christ, his mother, and many saints, all of whom thank Margery for writing her Book. 
Different from Julian, Margery is commanded to write about her feelings and her way of life to show God's goodness to the entire world. Her personal life is significant and an account of it has to be written down and published. At several points, Margery is ill and weak and only when she goes back to writing her Book is she suddenly cured again. Writing is treated in the same way as the rite of passage for becoming a prophet. God cures Margery as soon as she (re)commences writing, thus showing his grace and the importance of the written word.

The same holds true for seventeenth century visionary writers discussed here. They still felt the need to justify their writings, although many more women were able to publish between the 1640s and the 1660s. Trapnel, for instance, also insists on being nothing and on having been commanded by God to write about her travels to Cornwall. He is her instructor and tells her everything she needs to know to stand up to the people and the judges she encounters. Even though she maintains that she is inferior to the holy men and women in scripture, she still compares herself to Paul, and in calling herself a poor handmaid she identifies herself with the prophets in the Bible. God's testimony and his command allow her to justify her travels, to counter all the negative reports about her, and lend great importance to her texts in the first place. All these women are established as true seers, chosen by God to write about their lives and their thoughts. The seemingly complete loss of their voices and their selves, which in Wentworth's case came at a steep price, as her husband and her congregation continuously fought against her writings, give these women the necessary authority to make themselves heard and to be taken seriously. God's authority becomes their own authority to produce texts and to publish their thoughts and ideas.

The question of authority and authorship is further complicated by intermediaries, such as scribes, as well as by the insistence of these writers that they are merely vessels for the voice of God. Margery, for instance, has several scribes whose voices can be heard throughout the book. The lack of order and structure of the Book also calls the authenticity of the content into question. However, the different scribes and the structure of the Book become topics in their own right in the text. Indeed, the collaboration between Margery and the scribes, together with their testimonies at several points throughout the text bolster her credibility. Their scepticism and their 'conversion' by Margery and God invite the reader to follow a similar path. Even though one may be sceptical, the stories, miracles, and all the people converted into believers are meant to, likewise, convince the reader. Trapnel's scribe, who wrote down as 
much as he could during her trance, serves the same purpose. On several occasions he notes that he was not able to write down everything Trapnel had said and he even uses his own words to finish some of her songs or sentences. But his testimony and his introduction of Trapnel, her family, and her important acquaintances give her and her utterances even more credence. The scribe's questions and his own scepticism also anticipate the questions of the reader and lead the reader step by step to the necessary conclusion, namely that everything that Trapnel utters and that is written in the text must be the truth.

In addition, as vessels and mouthpieces of God, these female visionary writers seem to surrender the entire content of their texts to their Creator. Trapnel's statement in The Cry of a Stone encapsulates this issue perfectly: "Oh, it is for thy sake, and for thy servants sakes, that thy Servant is made a voyce, a sound, it is a voyce within a voyce, anothers voyce, even thy voyce through her" (42). The formula of a voice within a voice or God's voice speaking through her are meant to show that the visionary voice is not her own, but God's. However, all of these female prophets let their own voices clearly come through in their texts. Margery, for instance, even bargains with God in order to be granted her wish of being chaste along with many more wishes that are fulfilled throughout the Book. One of the most prominent features in her Book is the direct speech between her and Christ, where we can detect a clear distinction between Margery's voice and His. Trapnel, in turn, is better able to vindicate her life and her travels for the reader, and portrays herself as a singular prophet who knows God's secrets, some of which she is willing to share with us. In Wentworth's case, we hear about the entire struggle that she has to undergo to be able to write her texts. Her suffering is made open to the public and though she maintains that she only writes at God's command, her texts are ultimately her justification for leaving her husband and her congregation. All of these visionary writers are commanded to write texts in which they surrender their voices - sometimes to male scribes, but always to God - thereby giving up their authority, authorship, and voice to be able to write and publish in the first place. And yet, writing allows them to emerge with an even more distinct voice and an authority of their own. These texts show them to be strong women able to share their ideas, their political worldview, and their important religious insights. 